\title{
Rapid Upregulation of Orai1 Abundance in the Plasma Membrane of Platelets Following Activation with Thrombin and Collagen Related Peptide
}

\author{
Guilai Liu ${ }^{\mathrm{a}}$ Guoxing Liu ${ }^{\mathrm{a}}$ Hong Chen ${ }^{\mathrm{a}}$ Kousi Alzoubia Anja T. Umbach ${ }^{\mathrm{a}}$ \\ Meinrad Gawaz ${ }^{b}$ Christos Stournaras ${ }^{c}$ Florian Lang ${ }^{a}$
}

${ }^{a}$ Department of Physiology, ${ }^{b}$ Department of Cardiology and Cardiovascular Medicine, Eberhard-KarlsUniversity of Tübingen, Tübingen, Germany; 'Department of Biochemistry, University of Crete Medical School, Heraklion, Greece

\section{Key Words}

Cytosolic $\mathrm{Ca}^{2+}$ concentration $\bullet \mathrm{Rac} 1 \cdot \mathrm{SOCE} \cdot \mathrm{CRP}$

\begin{abstract}
Background: Blood platelets accomplish primary hemostasis following vascular injury and contribute to the orchestration of occlusive vascular disease. Platelets are activated by an increase of cytosolic $\mathrm{Ca}^{2+}$-activity $\left(\left[\mathrm{Ca}^{2+}\right]_{\mathrm{i}}\right)$, which is accomplished by $\mathrm{Ca}^{2+}$-release from intracellular stores and subsequent store operated $\mathrm{Ca}^{2+}$ entry (SOCE) through $\mathrm{Ca}^{2+}$ release activated $\mathrm{Ca}^{2+}$ channel moiety Orai1. Powerful activators of platelets include thrombin and collagen related peptide (CRP), which are in part effective by activation of small G- protein Rac1. The present study explored the influence of thrombin and CRP on Orail protein abundance and cytosolic Ca $\mathrm{Ca}^{2+}$-activity $\left(\left[\mathrm{Ca}^{2+}\right]_{\mathrm{j}}\right)$ in platelets drawn from wild type mice. Methods: Orai1 protein surface abundance was quantified utilizing $\mathrm{CF}^{\mathrm{TM}} 488 \mathrm{~A}$ conjugated antibodies, and $\left[\mathrm{Ca}^{2+}\right]_{i}$ was determined with Fluo3-fluorescence. Results: In resting platelets, Orai1 protein abundance and $\left[\mathrm{Ca}^{2+}\right]_{i}$ were low. Thrombin $(0.02$ $\mathrm{U} / \mathrm{ml})$ and CRP $(5 \mathrm{ug} / \mathrm{ml})$ within 2 min increased $\left[\mathrm{Ca}^{2+}\right]_{i}$ and Orai1 protein abundance at the platelet surface. $\left[\mathrm{Ca}^{2+}\right]_{\mathrm{i}}$ was further increased by $\mathrm{Ca}^{2+}$ ionophore ionomycin $(1 \mu \mathrm{M})$ and by store depletion with the sarcoendoplasmatic $\mathrm{Ca}^{2+}$ ATPase inhibitor thapsigargin $(1 \mu \mathrm{M})$. However, Orai1 protein abundance at the platelet surface was not significantly affected by ionomycin and only slightly increased by thapsigargin. The effect of thrombin and CRP on Orail abundance and $\left[\mathrm{Ca}^{2+}\right]_{i}$ was significantly blunted by Rac1 inhibitor NSC23766 $(50 \mu \mathrm{M})$. Conclusion: The increase of $\left[\mathrm{Ca}^{2+}\right]_{\mathrm{i}}$ following stimulation of platelets with thrombin and collagen related peptide is potentiated by ultrarapid Rac1 sensitive translocation of Orai1 into the cell membrane.
\end{abstract}

Copyright $\odot 2015$ S. Karger AG, Basel

G. Liu and G. Liu contributed equally and thus share first authorship; C. Stournaras and F. Lang contributed equally and thus share last authorship.

Florian Lang

KARGER 125
Department of Physiology, University of Tübingen,

Gmelinstr. 5, 72076 Tübingen, (Germany)

Tel. +49 7071 29-72194, Fax +49 7071 29-5618, E-Mail florian.lang@uni-tuebingen.de 


\begin{tabular}{|c|c|c|}
\hline Cellular Physiology & Cell Physiol Biochem 2015;37:1759-1760 & \\
\hline and Biochemistry & $\begin{array}{l}\text { Dol: 10.1159/000438539 } \\
\text { Published online: November 13, } 2015\end{array}$ & $\begin{array}{l}\text { O } 2015 \text { S. Karger AG, Base } \\
\text { www.karger.com/cpb }\end{array}$ \\
\hline
\end{tabular}

\section{Introduction}

Platelets accomplish primary hemostasis following vascular injury requiring almost immediate activation. Platelets are activated by an increase of cytosolic $\mathrm{Ca}^{2+}$ activity $\left(\left[\mathrm{Ca}^{2+}\right]_{\mathrm{i}}\right)[1]$, which is accomplished by $\mathrm{Ca}^{2+}$ release from intracellular stores and by $\mathrm{Ca}^{2+}$ entry from extracellular space [2]. $\mathrm{Ca}^{2+}$ entry is activated by intracellular $\mathrm{Ca}^{2+}$ store depletion, which is sensed by the stromal interaction molecule 1 (STIM1) [3]. Following store depletion STIM1 activates the pore forming unit of the $\mathrm{Ca}^{2+}$ release-activated channel (CRAC) Orai1 (CRACM1) in the plasma membrane $[1,4-6]$. STIM1/Orai1 thus accomplish store-operated $\mathrm{Ca}^{2+}$ entry (SOCE) [7, 8], which is decisive for platelet activation $[1,2,5,9]$. The increase of $\left[\mathrm{Ca}^{2+}\right]_{\mathrm{i}}$ triggers cytoskeletal reorganization [10] and apoptosis-like phosphatidylserine translocation to the platelet membrane surface [6]. Stimulation of platelets further leads to activation of the small G-protein Rac1 [11-19], which in turn participates in the regulation of actin polymerization [12,16-18]. Upon activation, Rac1 is translocated to the cell membrane [20].

Activators of Orai1 include thrombin and collagen related peptide (CRP) [21, 22]. Thrombin has further been shown to up-regulate Orai1 expression by stimulating Orai1 translation [23]. The present study explored whether thrombin and collagen related peptide were able to modify Orai1 protein abundance in the platelet membrane within 2 minutes, i.e. in a time period too short for synthesis of novel protein. As a result, Orai1 protein abundance was upregulated by thrombin and collagen related peptide within 2 min, an effect highly sensitive to Rac1.

\section{Materials and Methods}

Mice

All animal experiments were conducted according to the German law for the welfare of animals and were approved by the authorities of the state of Baden-Württemberg. Experiments were performed with blood platelets isolated from wild type C57/BL6 mice mice. The mice had free access to water and control chow (Ssniff, Soest, Germany).

\section{Preparation of mouse platelets}

Platelets were obtained from 10 - to 12 -week-old mice of either sex. The mice were anesthetized and $800 \mu \mathrm{l}$ blood was drawn from the retro-orbital plexus into tubes with $300 \mu \mathrm{l}$ acid-citrate-dextrose buffer before the mice were sacrificed due to the large volume of blood drawn $[21,22]$. Platelet rich plasma (PRP) was obtained by centrifugation at $260 \mathrm{~g}$ for 5 minutes. Afterwards PRP was centrifuged at $640 \mathrm{~g}$ for 5 minutes to pellet the platelets. Where necessary apyrase $(0.02 \mathrm{U} / \mathrm{ml}$; Sigma-Aldrich) and prostaglandin $\mathrm{I}_{2}(0.5 \mu \mathrm{M}$; Calbiochem $)$ were added to the PRP to prevent activation of platelets during isolation. After two washing steps the pellet of washed platelets was resuspended in modified Tyrode-HEPES buffer ( $\mathrm{pH}$ 7.4, supplemented with $1 \mathrm{mM} \mathrm{CaCl}_{2}$ ). Where indicated, thrombin (0.02 U/ml, Roche, Basel, Switzerland), collagen related peptide (CRP, kindly provided by R.Farndale, University of Cambridge, Cambridge, UK), $\mathrm{Ca}^{2+}$ ionophore ionomycin ( $1 \mu \mathrm{M}$, Sigma, Germany), sarcoendoplasmatic $\mathrm{Ca}^{2+}$ ATPase inhibitor thapsigargin (1 $\mu \mathrm{M}$, Molecular Probes), Rac 1 inhibitor NSC23766 (50 $\mu \mathrm{M}$, Tocris Bioscience, UK) were added [24, 25].

Orai1 surface protein abundance

Orai1 surface expression was analyzed in platelets by flow cytometry. Washed platelets were incubated with thrombin or CRP for 2 min and subsequently fixed with $1 \%$ paraformaldehyde for 30 min on ice. After rinsing three times, platelets were incubated for 60 minutes $\left(37^{\circ} \mathrm{C}\right)$ with Orai1 rabbit anti-mouse antibody (Abcam) [26], washed once in Tyrode buffer, and stained in 1:250 diluted $\mathrm{CF}^{\mathrm{TM}}$ 488A-labeled anti-rabbit secondary antibody (Sigma, USA) for 30 minutes $\left(37^{\circ} \mathrm{C}\right)$. Samples were immediately analyzed on a FACS Calibur flow cytometer (BD Biosciences).

\section{KARGER}




\begin{tabular}{|c|c|c|}
\hline Cellular Physiology & Cell Physiol Biochem 2015;37:1759-1766 & \\
\hline and Biochemistry & $\begin{array}{l}\text { DOI: 10.1159/000438539 } \\
\text { Published online: November 13, } 2015\end{array}$ & $\begin{array}{l}\text { O } 2015 \mathrm{~S} \text { S. Karger AG, Basel } \\
\text { www.karger.com/cpb }\end{array}$ \\
\hline
\end{tabular}

Calcium measurements

For the measurement of the intracellular $\mathrm{Ca}^{2+}$ concentration the platelet preparation was washed once in Tyrode buffer (pH 7.4), stained with $3 \mu$ M Fluo-3AM (Biotinium, USA) in the same buffer and incubated at $37^{\circ} \mathrm{C}$ for 30 minutes. Following the indicated experimental treatment, fluorescence was measured at an excitation wavelength of $488 \mathrm{~nm}$ and an emission wavelength of $530 \mathrm{~nm}$ utilizing a BD FACSCalibur (BD Biosciences, Heidelberg, Germany) [27].

\section{Statistical analysis}

Data are provided as means \pm SEM; $n$ represents the number of independent experiments. All data were tested for significance using ANOVA with Tukey's test as post-test or unpaired student's t-test as appropriate. Results with $p<0.05$ were considered statistically significant.

\section{Results}

The present study addressed the influence of thrombin and collagen related peptide on Orai1 protein abundance in the platelet cell membrane and platelet cytosolic $\mathrm{Ca}^{2+}$ concentration. As illustrated in Fig. 1, exposure of murine blood platelets for 2 minutes to thrombin (0.02 U/ $\mathrm{ml}$ ) or collagen related peptide $(5 \mathrm{ug} / \mathrm{ml})$ was followed by a marked increase of Orai1 protein abundance in the plasma membrane. Considering the rapidity of Orai1 appearance in the platelet plasma membrane, the effect was most likely due to translocation of preformed Orai1 protein into the plasma membrane. The increase of Orai1 protein abundance was paralleled by an increase of Fluo-3 fluorescence reflecting increase of cytosolic $\mathrm{Ca}^{2+}$ activity $\left(\left[\mathrm{Ca}^{2+}\right]_{\mathrm{i}}\right)$.

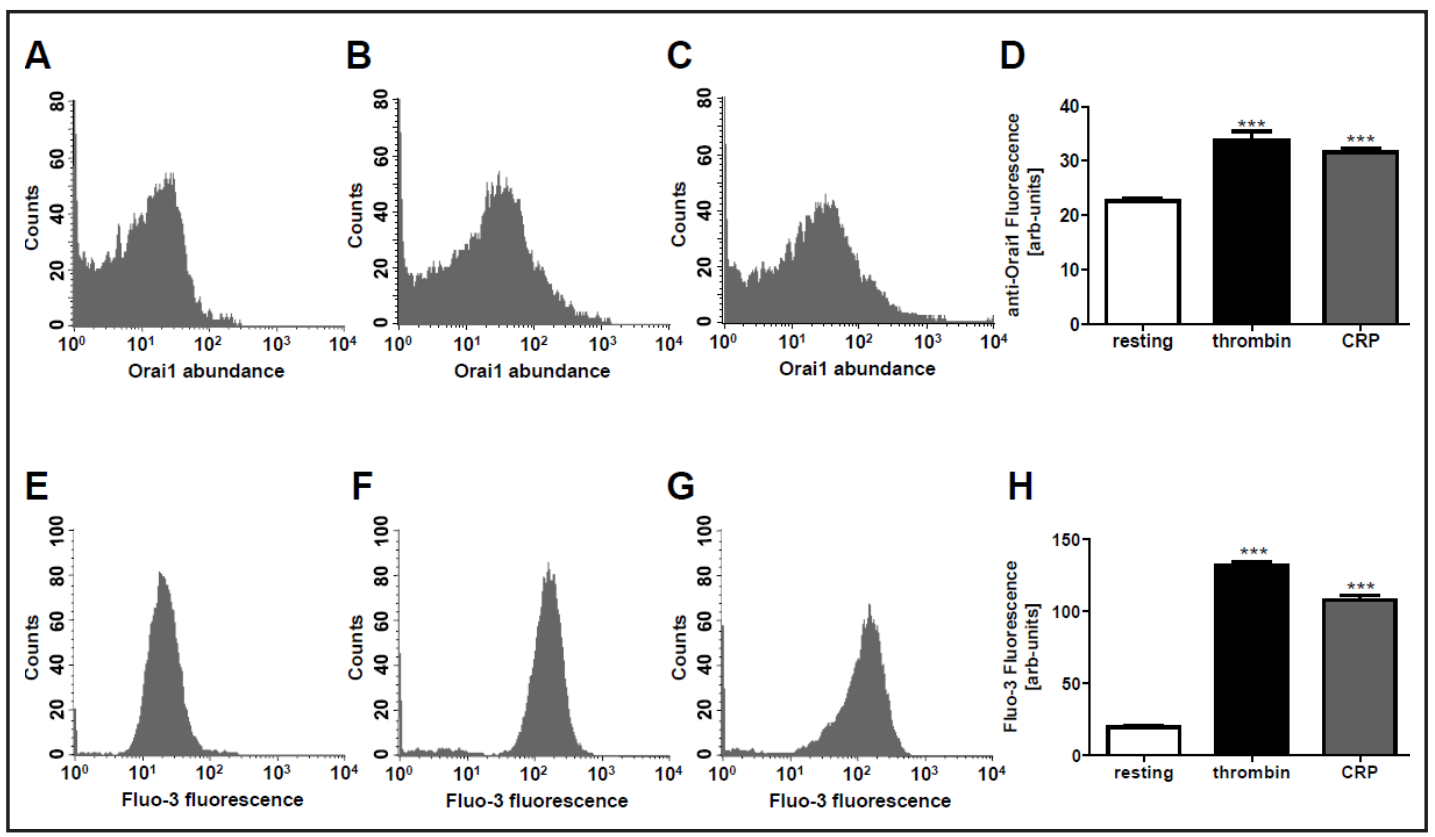

Fig. 1. Effect of thrombin and collagen related peptide on Orai1 protein abundance in the platelet cell membrane and platelet cytosolic $\mathrm{Ca}^{2+}$ concentration. A,B,C. Original histograms of anti-Orai1 fluorescence in platelets isolated from wild type mice prior to (A) and following a 2 min treatment with $0.02 \mathrm{U} / \mathrm{ml}$ thrombin (B) or $5 \mu \mathrm{g} / \mathrm{ml}$ collagen related peptide (C). D. Arithmetic means \pm SEM $(n=4)$ of the anti-Orai1 fluorescence (arbitrary fluorescence units) in murine platelets prior to (white bar) and following a 2 min treatment with thrombin (0.02 U/ml) (black bar) or collagen related peptide (CRP, $5 \mu \mathrm{g} / \mathrm{ml}$ ) (grey bar). E,F,G. Original histograms of Fluo-3 fluorescence in platelets isolated from wild type mice prior to (E) and following a 2 min treatment with $0.02 \mathrm{U} / \mathrm{ml}$ thrombin $(\mathrm{F})$ or $5 \mu \mathrm{g} / \mathrm{ml}$ collagen related peptide $(\mathrm{G})$. H. Arithmetic means $\pm \mathrm{SEM}$ ( $n=4)$ of Fluo-3 fluorescence (arbitrary fluorescence units) in murine platelets prior to (white bar) and following a $2 \mathrm{~min}$ treatment with thrombin $(0.02 \mathrm{U} / \mathrm{ml})$ (black bar) or collagen related peptide (CRP, $5 \mu \mathrm{g} / \mathrm{ml}$ ) (grey bar). ${ }^{* * *}(\mathrm{P}<0.001)$ indicates statistically significant difference to absence of thrombin and CRP. 
Fig. 2. Effect of $\mathrm{Ca}^{2+}$ ionophore ionomycin on Orai1 protein abundance in the platelet cell membrane and platelet cytosolic $\mathrm{Ca}^{2+}$ concentration. A. Original histogram overlays of anti-Orai1 fluorescence in platelets isolated from wild type mice without (grey shadow) and with (black line) a 2 min prior treatment with ionomycin $(1 \mu \mathrm{M})$. B. Arithmetic means \pm SEM $(n=6)$ of the anti-Orai1 fluorescence (arbitrary fluorescence units) in murine platelets prior to (white bar) and following (black bar) a 2 min treatment with ionomycin $(1 \mu \mathrm{M})$. C. Original histogram overlays of Fluo-3 fluorescence in platelets isolated from wild type mice wi-

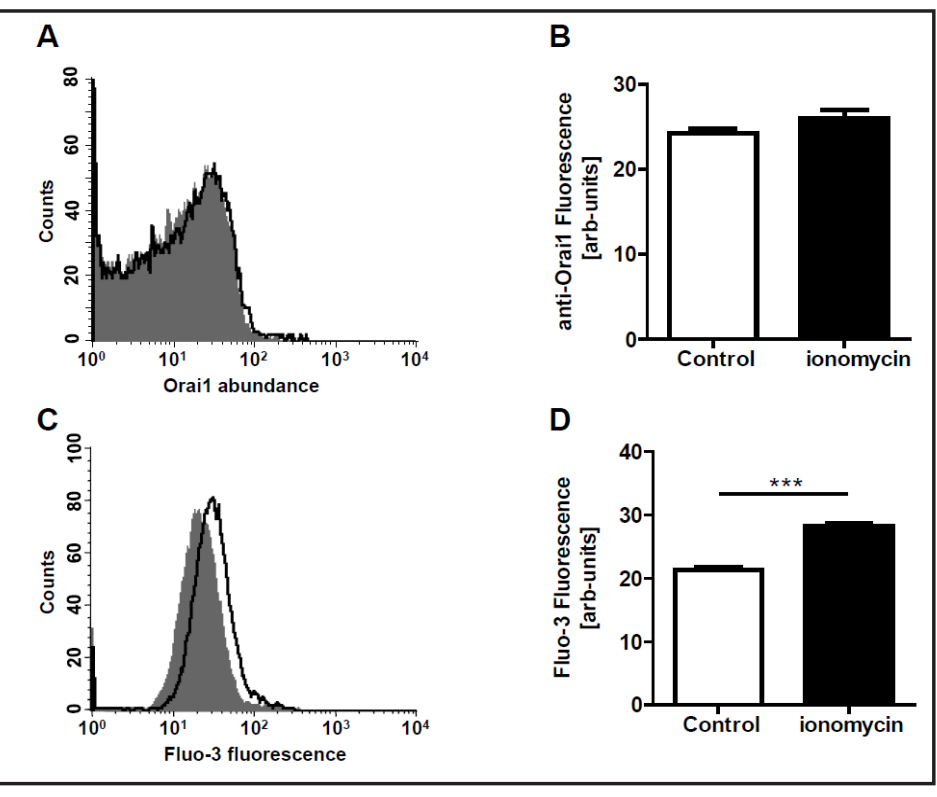
thout (grey shadow) and with (black line) a 2 min prior treatment with ionomycin $(1 \mu \mathrm{M})$. D. Arithmetic means \pm SEM $(n=6)$ of Fluo-3 fluorescence (arbitrary fluorescence units) in murine platelets prior to (white bar) and following (black bar) a 2 min treatment with ionomycin $(1 \mu \mathrm{M}) .{ }^{* * *}(\mathrm{p}<0.001)$ indicates statistically significant difference to absence of ionomycin.

Fig. 3. Effect of sarcoendoplasmatic $\mathrm{Ca}^{2+}$ ATPase inhibitor thapsigargin on Orai1 protein abundance in the platelet cell membrane and platelet cytosolic $\mathrm{Ca}^{2+}$ concentration. A. Original histogram overlays of anti-Orai1 fluorescence in platelets isolated from wild type mice without (grey shadow) and with (black line) a $10 \mathrm{~min}$ prior treatment with thapsigargin (1 $\mu \mathrm{M})$. B. Arithmetic means \pm SEM $(n=6)$ of the anti-Orai1 fluorescence (arbitrary fluorescence units) in murine platelets prior to (white bar) and following (black bar) a 10 min treatment with thapsigargin $(1 \mu \mathrm{M})$. C. Original histogram overlays of Fluo-3 fluorescence in

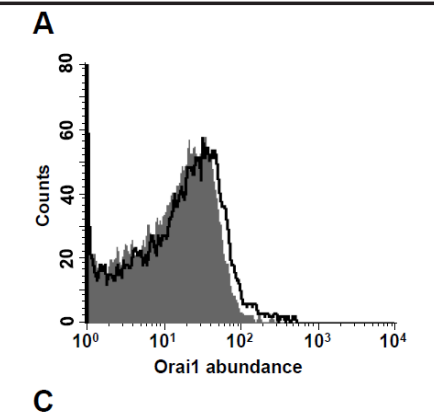

C

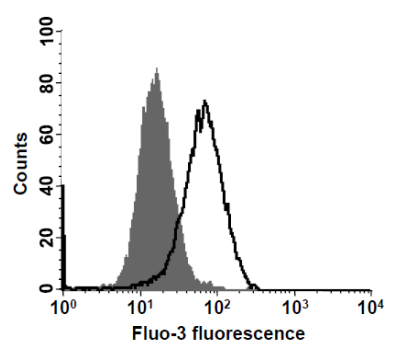

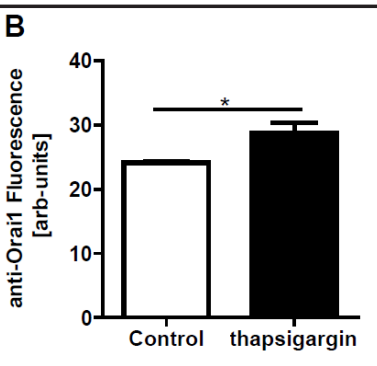

D

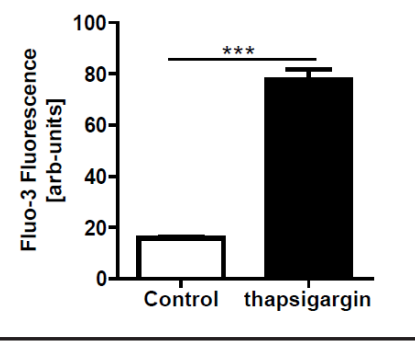
platelets isolated from wild type mice without (grey shadow) and with (black line) a 10 min prior treatment with thapsigargin $(1 \mu \mathrm{M})$. D. Arithmetic means \pm SEM $(n=6)$ of Fluo-3 fluorescence (arbitrary fluorescence units) in murine platelets prior to (white bar) and following (black bar) a 10 min treatment with thapsigargin $(1 \mu \mathrm{M}) .{ }^{*}(\mathrm{p}<0.05)$ and ${ }^{* * *}(\mathrm{p}<0.001)$ indicate statistically significant difference to absence of thapsigargin,

In theory, the effect of thrombin and collagen related peptide on Orai1 protein abundance in the plasma membrane could have resulted from a stimulating effect of increased $\left[\mathrm{Ca}^{2+}\right]_{\mathrm{i}}$ on fusion of Orai1 containing intracellular vesicles with the plasma membrane. To test this possibility, $\left[\mathrm{Ca}^{2+}\right]_{\mathrm{i}}$ was increased in additional experiments by treatment of the platelets with the $\mathrm{Ca}^{2+}$ ionophore ionomycin. As illustrated in Fig. 2, treatment of murine platelets with ionomycin $(1 \mu \mathrm{M})$ was followed by the expected increase of $\left[\mathrm{Ca}^{2+}\right]_{i}$, but did not significantly 


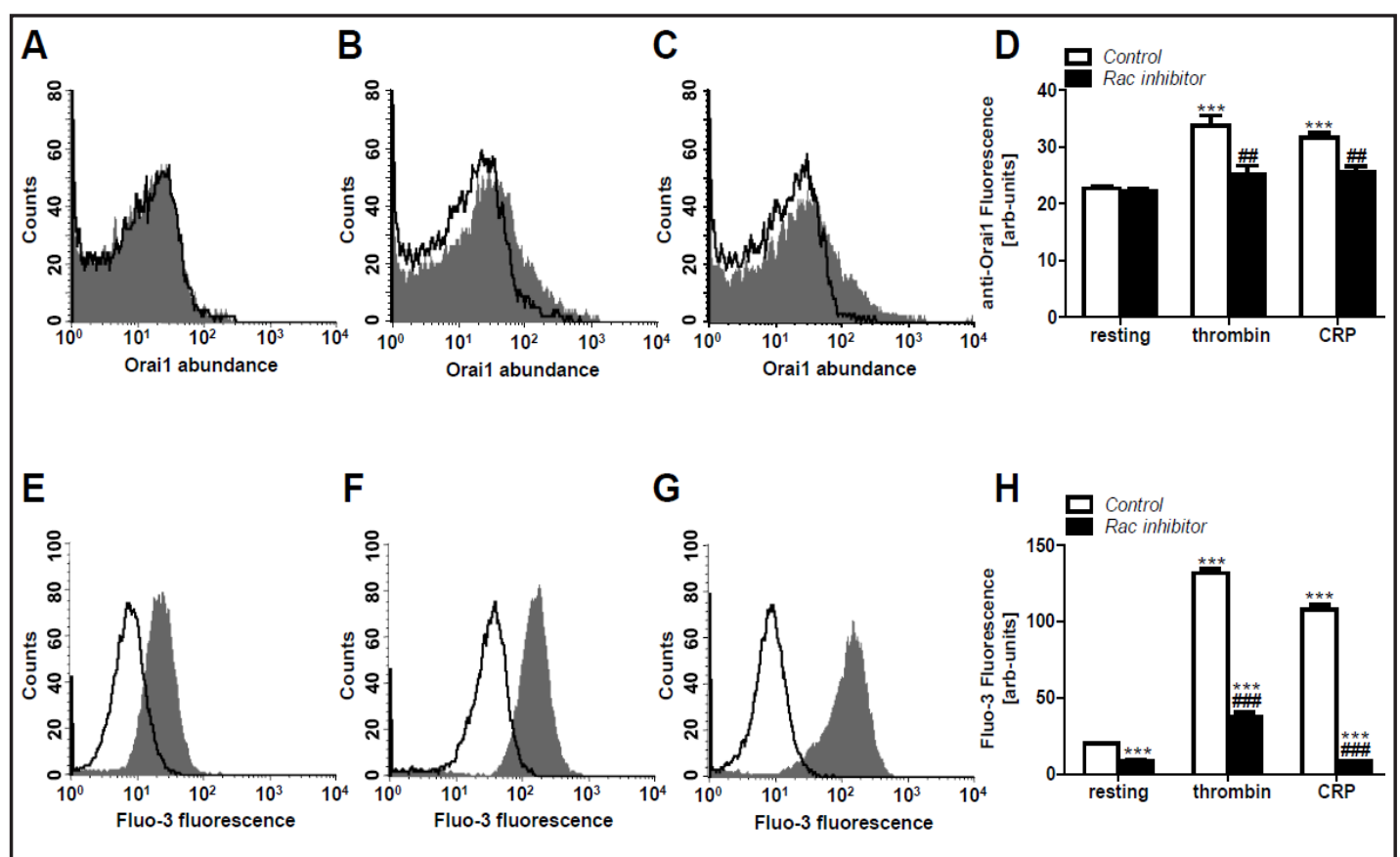

Fig. 4. Effect of thrombin and collagen related peptide on Orai1 protein abundance in the platelet cell membrane and platelet cytosolic $\mathrm{Ca}^{2+}$ concentration in absence and presence of Rac inhibitor NSC23766. A,B,C. Original histogram overlays of anti-Orai1 fluorescence in platelets isolated from wild type mice without (grey shadows) and with (black lines) the presence of $50 \mu \mathrm{M}$ Rac inhibitor NSC23766 prior to (A) and following a $2 \mathrm{~min}$ treatment with $0.02 \mathrm{U} / \mathrm{ml}$ thrombin (B) or $5 \mu \mathrm{g} / \mathrm{ml}$ collagen related peptide (C). D. Arithmetic means \pm SEM $(n=4)$ of the anti-Orai1 fluorescence (arbitrary fluorescence units) in murine platelets without (white bar) and with (black bar) the presence of $50 \mu \mathrm{M}$ Rac inhibitor NSC23766 prior to and following a 2 min treatment with thrombin $(0.02 \mathrm{U} / \mathrm{ml})$ or collagen related peptide (CRP, $5 \mu \mathrm{g} / \mathrm{ml})$. E,F,G. Original histogram overlays of Fluo-3 fluorescence in platelets isolated from wild type mice without (grey shadows) and with (black lines) the presence of $50 \mu \mathrm{M}$ Rac inhibitor NSC23766 prior to (E) and following a 2min prior treatment with $0.02 \mathrm{U} / \mathrm{ml}$ thrombin (F) or $5 \mu \mathrm{g} / \mathrm{ml}$ collagen related peptide (G). H. Arithmetic means $\pm \mathrm{SEM}(\mathrm{n}=$ 4-6) of Fluo-3 fluorescence (arbitrary fluorescence units) in murine platelets without (white bars) and with (black bars) the presence of $50 \mu \mathrm{M}$ Rac inhibitor NSC23766 prior to and following a 2 min treatment with thrombin $(0.02 \mathrm{U} / \mathrm{ml})$ or collagen related peptide (CRP, $5 \mu \mathrm{g} / \mathrm{ml})$. ${ }^{* *}(\mathrm{P}<0.001)$ indicates statistically significant difference to absence of thrombin and CRP, \#\# $(\mathrm{p}<0.01)$ and \#\#\#(p<0.001) indicate statistically significant difference to absence of Rac inhibitor NSC23766.

modify the Orai1 abundance in the platelet plasma membrane. Thus, increase of $\left[\mathrm{Ca}^{2+}\right]_{\mathrm{i}}$ alone did not explain the ultrarapid increase of Orai1 protein abundance in the cell membrane.

The effect of thrombin and collagen related peptide on Orai1 protein abundance in the plasma membrane could further have resulted from a stimulating effect of intracellular store depletion on Orai1 insertion into the plasma membrane. To test this possibility, the intracellular stores were depleted in additional experiments by treatment of the platelets with the sarcoendoplasmatic $\mathrm{Ca}^{2+}$ ATPase inhibitor thapsigargin. As shown in Fig. 3, treatment of murine platelets with thapsigargin $(1 \mu \mathrm{M})$ was followed by the expected increase of $\left[\mathrm{Ca}^{2+}\right]_{\mathrm{i}}$ due to emptying of intracellular stores, and slightly, but significantly, increased the Orai1 abundance in the platelet plasma membrane.

In order to test whether upregulation of Orai1 abundance in the platelet plasma membrane involved the small G-protein Rac1, additional experiments were performed elucidating the effect of thrombin and collagen related peptide in the presence of the Rac1 inhibitor NSC23766 $(50 \mu \mathrm{M})$, added $1 \mathrm{~h}$ prior to the administration of thrombin and collagen related peptide. As illustrated in Fig. 4A-D, the effect of thrombin and collagen related peptide on 
Orai1 protein abundance in the platelet plasma membrane was blunted in the presence of Rac1 inhibitor NSC23766. The blunted thrombin- and CRP- induced increase of Orai1 protein abundance in the platelet plasma membrane in the presence of Rac1 inhibitor NSC23766 was paralleled by a blunted thrombin- and CRP- induced increase of $\left[\mathrm{Ca}^{2+}\right]_{\mathrm{i}}$ (Fig. 4E-H), an observation pointing to the functional significance of ultrarapid Orai1 recruitment to the plasma membrane.

\section{Discussion}

The present observations reveal that thrombin and collagen related peptide within 2 min increased Orai1 protein abundance at the platelet surface, an effect presumably in large part due to translocation of preformed channel protein from intracellular vesicles into the cell membrane. The increase of Orai1 protein abundance in the cell membrane substantially augments the increase of cytosolic $\mathrm{Ca}^{2+}$ activity $\left(\left[\mathrm{Ca}^{2+}\right]_{\mathrm{i}}\right)$. The present study further shed light on the mechanism underlying the ultrarapid translocation of the Orai1 channel protein into the platelet plasma membrane. Somewhat surprisingly, increase of $\left[\mathrm{Ca}^{2+}\right]_{i}$ by $\mathrm{Ca}^{2+}$ ionophore ionomycin did not significantly modify the Orai1 protein abundance in the cell membrane. Store depletion by treatment with the sarcoendoplasmatic $\mathrm{Ca}^{2+}$ ATPase inhibitor thapsigargin only slightly, but significantly, increased Orai1 protein abundance in the cell membrane. Depletion of intracellular $\mathrm{Ca}^{2+}$ stores is well known to activate STIM1 [28], the sensor of the $\mathrm{Ca}^{2+}$ content in the sarcoendoplasmatic reticulum [29]. Upon store depletion STIM1 activates Orai1 [30, 31]. In view of the small effect of store depletion on Orai1 abundance STIM may further slightly trigger Orai1 translocation into the cell membrane. However, the increase of Orai1 protein abundance at the platelet surface following stimulation with thrombin is apparently in large part accomplished by mechanisms other than store depletion or subsequent increase of $\left[\mathrm{Ca}^{2+}\right]_{\mathrm{i}}$. The observations following inhibition of the small G- protein Rac1 with Rac1 inhibitor NSC23766 suggests the involvement of Rac1 in the translocation of Orai1 into the platelet plasma membrane.

Activation of Orai1 and subsequent increase of $\left[\mathrm{Ca}^{2+}\right]_{\mathrm{i}}$ is pivotal for platelet activation with thrombus formation and platelet apoptosis with phospatidylserine translocation to the cell surface [6]. To the extent that Rac1 activity enhances Orai1 abundance and thus augments $\mathrm{Ca}^{2+}$ entry and increase of $\left[\mathrm{Ca}^{2+}\right]_{i}$, the small G-protein participates in the tuning of platelet activation. Orai1 and STIM1 are essential for full platelet activation $[5,29,32]$ and up-regulation of Orai1 amplifies platelet activation and hemostasis [33]. The up-regulation of Orai1 thus contributes to the known impact of Rac1 on platelet activation and apoptosis [1119].

$\mathrm{Ca}^{2+}$ entry could be accomplished by further mechanisms in addition to Orai1 [34]. The mechanisms include TMEM16F, a Ca ${ }^{2+}$-activated, $\mathrm{Ca}^{2+}$-permeable channel with scramblase activity [35] and by the nonselective transient receptor potential (TRP) cation channels TRPC3 and TRPC6, which primarily increase $\mathrm{Na}^{+}$entry leading to increase of cytosolic $\mathrm{Na}^{+}$ activity, reversal of $\mathrm{Na}^{+} / \mathrm{Ca}^{2+}$ exchange and thus increase of $\left[\mathrm{Ca}^{2+}\right]_{\mathrm{i}}[35]$. Those mechanisms are, however, not able to maintain normal platelet function, as lack of Orai1 leads to a severe bleeding disorder [5].

Orai1 protein abundance in the plasma membrane is of pathophysiological significance, as stimulation of platelet degranulation, adhesion and aggregation by increase of $\left[\mathrm{Ca}^{2+}\right]_{\mathrm{i}}$ contributes to development of thrombosis [1]. Increase of $\left[\mathrm{Ca}^{2+}\right]_{i}$ following Orai1 activation further triggers phospholipid scrambling of the cell membrane with translocation of phosphatidylserine to the platelet surface [35-38]. Along those lines enhanced Orai1 activity with subsequent increase of $\left[\mathrm{Ca}^{2+}\right]_{i}$ contributes to the pathophysiology of acute thrombotic occlusion following atherosclerotic plaque rupture [38, 39].

In conclusion, activation of blood platelets by thrombin and collagen related peptide involves ultrarapid Rac1 sensitive translocation of Orai1 into the platelet plasma membrane. The translocation of Orai1 amplifies $\mathrm{Ca}^{2+}$ entry and thus platelet activation. 


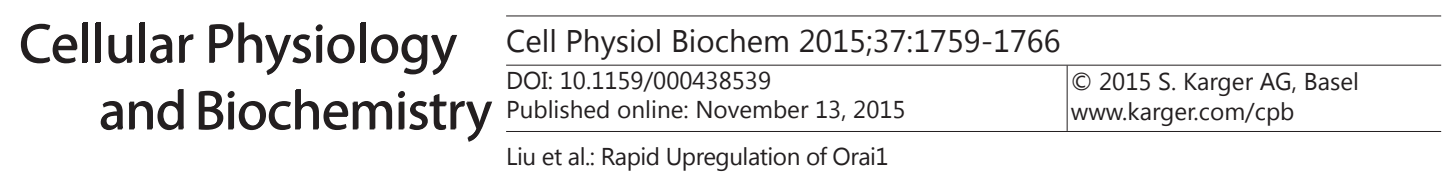

\section{Disclosure Statement}

The authors of this manuscript state that they have no conflicts of interest to declare.

\section{Acknowledgements}

The study was supported by the Deutsche Forschungsgemeinschaft KFO 274, and Open Access Publishing Fund of Tuebingen University.

We do confirm that the funder had played no role in study design, collection, analysis and interpretation of data, writing of the report and in the decision to submit the article for publication.

\section{References}

1 Bergmeier W, Stefanini L: Novel molecules in calcium signaling in platelets. J Thromb Haemost 2009; 7:S187-190.

2 Varga-Szabo D, Braun A, Nieswandt B: Calcium signaling in platelets. J Thromb Haemost 2009;7:10571066.

3 Shuttleworth TJ, Thompson JL, Mignen O: STIM1 and the noncapacitative ARC channels. Cell Calcium 2007;42:183-191.

4 Wang Y, Deng X, Gill DL: Calcium signaling by STIM and Orai: intimate coupling details revealed. Sci Signal 2010;3:e42.

5 Braun A, Varga-Szabo D, Kleinschnitz C, Pleines I, Bender M, Austinat M, Bosl M, Stoll G, Nieswandt B: Orai1 (CRACM1) is the platelet SOC channel and essential for pathological thrombus formation. Blood 2009;113:2056-2063.

6 Varga-Szabo D, Braun A, Nieswandt B: STIM and Orai in platelet function. Cell Calcium 2011;50:270-278.

7 Parekh AB: Store-operated CRAC channels: function in health and disease. Nat Rev Drug Discov 2010;9:399-410.

8 Braun A, Vogtle T, Varga-Szabo D, Nieswandt B: STIM and Orai in hemostasis and thrombosis. Front Biosci (Landmark Ed) 2011;16:2144-2160.

9 Kile BT: The role of apoptosis in megakaryocytes and platelets. Br J Haematol 2014;165:217-226.

10 Bearer EL, Prakash JM, Li Z: Actin dynamics in platelets. Int Rev Cytol 2002;217:137-182.

11 Delaney MK, Liu J, Kim K, Shen B, Stojanovic-Terpo A, Zheng Y, Cho J, Du X: Agonist-induced platelet procoagulant activity requires shear and a Rac1-dependent signaling mechanism. Blood 2014;124:19571967.

12 Dwivedi S, Pandey D, Khandoga AL, Brandl R, Siess W: Rac1-mediated signaling plays a central role in secretion-dependent platelet aggregation in human blood stimulated by atherosclerotic plaque. J Transl Med 2010;8:128.

13 Elsaraj SM, Bhullar RP: Regulation of platelet Rac1 and Cdc42 activation through interaction with calmodulin. Biochim Biophys Acta 2008;1783:770-778.

14 Fleming IN, Batty IH, Prescott AR, Gray A, Kular GS, Stewart H, Downes CP: Inositol phospholipids regulate the guanine-nucleotide-exchange factor Tiam 1 by facilitating its binding to the plasma membrane and regulating GDP/GTP exchange on Rac1. Biochem J 2004;382:857-865.

15 Knezevic, II, Predescu SA, Neamu RF, Gorovoy MS, Knezevic NM, Easington C, Malik AB, Predescu DN: Tiam 1 and Rac1 are required for platelet-activating factor-induced endothelial junctional disassembly and increase in vascular permeability. J Biol Chem 2009;284:5381-5394.

16 McCarty OJ, Larson MK, Auger JM, Kalia N, Atkinson BT, Pearce AC, Ruf S, Henderson RB, Tybulewicz VL, Machesky LM, Watson SP: Rac1 is essential for platelet lamellipodia formation and aggregate stability under flow. J Biol Chem 2005;280:39474-39484.

17 Pandey D, Goyal P, Dwivedi S, Siess W: Unraveling a novel Rac1-mediated signaling pathway that regulates cofilin dephosphorylation and secretion in thrombin-stimulated platelets. Blood 2009;114:415-424.

18 Vidal C, Geny B, Melle J, Jandrot-Perrus M, Fontenay-Roupie M: Cdc42/Rac1-dependent activation of the p21-activated kinase (PAK) regulates human platelet lamellipodia spreading: implication of the corticalactin binding protein cortactin. Blood 2002;100:4462-4469. 


\section{Cellular Physiology Cell Physiol Biochem 2015;37:1759-1766

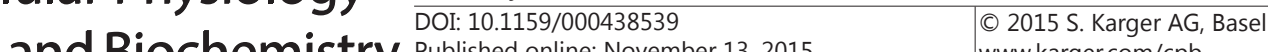 and Biochemistry Published online: November 13, 2015 \\ Liu et al.: Rapid Upregulation of Orai1}

19 Calaminus SD, McCarty OJ, Auger JM, Pearce AC, Insall RH, Watson SP, Machesky LM: A major role for Scar/ WAVE-1 downstream of GPVI in platelets. J Thromb Haemost 2007;5:535-541.

20 Moissoglu K, Kiessling V, Wan C, Hoffman BD, Norambuena A, Tamm LK, Schwartz MA: Regulation of Rac1 translocation and activation by membrane domains and their boundaries. J Cell Sci 2014;127:2565-2576.

21 Pelzl L, Fakhri H, Umbach AT, Gawaz M, Paulmichl M, Lang F: Sgk1 sensitive pendrin expression in murine platelets. Cell Physiol Biochem 2013;32:210-220.

22 Borst O, Walker B, Munzer P, Russo A, Schmid E, Faggio C, Bigalke B, Laufer S, Gawaz M, Lang F: Skepinone-L, a novel potent and highly selective inhibitor of p38 MAP kinase, effectively impairs platelet activation and thrombus formation. Cell Physiol Biochem 2013;31:914-924.

23 Munzer P, Tolios A, Pelzl L, Schmid E, Schmidt EM, Walker B, Frohlich H, Borst O, Gawaz M, Lang F: Thrombin-sensitive expression of the store operated $\mathrm{Ca}(2+)$ channel Orai1 in platelets. Biochem Biophys Res Commun 2013;436:25-30.

24 Schmidt EM, Kraemer BF, Borst O, Munzer P, Schonberger T, Schmidt C, Leibrock C, Towhid ST, Seizer P, Kuhl D, Stournaras C, Lindemann S, Gawaz M, Lang F: SGK1 sensitivity of platelet migration. Cell Physiol Biochem. 2012;30:259-268.

25 Borst O, Schmidt EM, Munzer P, Schonberger T, Towhid ST, Elvers M, Leibrock C, Schmid E, Eylenstein A, Kuhl D, May AE, Gawaz M, Lang F: The serum- and glucocorticoid-inducible kinase 1 (SGK1) influences platelet calcium signaling and function by regulation of Orai1 expression in megakaryocytes. Blood 2012;119:251-261.

26 Liu G, Liu G, Alzoubi K, Umbach AT, Pelzl L, Borst O, Gawaz M, Lang F: Upregulation of store operated Ca channel Orai1, stimulation of $\mathrm{Ca}(2+)$ entry and triggering of cell membrane scrambling in platelets by mineralocorticoid DOCA. Kidney Blood Press Res 2013;38:21-30.

27 Towhid ST, Schmidt EM, Tolios A, Munzer P, Schmid E, Borst O, Gawaz M, Stegmann E, Lang F: Stimulation of platelet death by vancomycin. Cell Physiol Biochem 2013;31:102-112.

28 Zhang SL, Yu Y, Roos J, Kozak JA, Deerinck TJ, Ellisman MH, Stauderman KA, Cahalan MD: STIM1 is a Ca2+ sensor that activates CRAC channels and migrates from the Ca2+ store to the plasma membrane. Nature 2005;437:902-905.

29 Varga-Szabo D, Braun A, Kleinschnitz C, Bender M, Pleines I, Pham M, Renne T, Stoll G, Nieswandt B: The calcium sensor STIM1 is an essential mediator of arterial thrombosis and ischemic brain infarction. J Exp Med 2008;205:1583-1591.

30 Prakriya M, Feske S, Gwack Y, Srikanth S, Rao A, Hogan PG: Orai1 is an essential pore subunit of the CRAC channel. Nature 2006;443:230-233.

31 Vig M, Peinelt C, Beck A, Koomoa DL, Rabah D, Koblan-Huberson M, Kraft S, Turner H, Fleig A, Penner $\mathrm{R}$, Kinet JP: CRACM1 is a plasma membrane protein essential for store-operated Ca2+ entry. Science 2006;312:1220-1223.

32 Galan C, Zbidi H, Bartegi A, Salido GM, Rosado JA: STIM1, Orai1 and hTRPC1 are important for thrombinand ADP-induced aggregation in human platelets. Arch Biochem Biophys 2009;490:137-144.

33 Gawaz M: The evolving science of atherothrombotic disease. Eur Heart J 2008;10:I4-I7.

34 Gilio K, van Kruchten R, Braun A, Berna-Erro A, Feijge MA, Stegner D, van der Meijden PE, Kuijpers MJ, Varga-Szabo D, Heemskerk JW, Nieswandt B: Roles of platelet STIM1 and Orai1 in glycoprotein VI- and thrombin-dependent procoagulant activity and thrombus formation. J Biol Chem 2010;285:23629-23638.

35 Mahaut-Smith MP: A role for platelet TRPC channels in the Ca2+ response that induces procoagulant activity. Sci Signal 2013;6:pe23.

36 Harper MT, Poole AW: Store-operated calcium entry and non-capacitative calcium entry have distinct roles in thrombin-induced calcium signalling in human platelets. Cell Calcium 2011;50:351-358.

37 Mushtaq M, Nam TS, Kim UH: Critical role for CD38-mediated Ca2+ signaling in thrombin-induced procoagulant activity of mouse platelets and hemostasis. J Biol Chem 2011;286:12952-12958.

38 Borst O, Munzer P, Gatidis S, Schmidt EM, Schonberger T, Schmid E, Towhid ST, Stellos K, Seizer P, May AE, Lang F, Gawaz M: The inflammatory chemokine CXC motif ligand 16 triggers platelet activation and adhesion via CXC motif receptor 6-dependent phosphatidylinositide 3-kinase/Akt signaling. Circ Res 2012;111:1297-1307.

39 Gawaz M: Role of platelets in coronary thrombosis and reperfusion of ischemic myocardium. Cardiovasc Res 2004;61:498-511. 